\title{
Financial Deepening and Unemployment in Nigeria: A Causal Analysis
}

\author{
Osuka B. O. ${ }^{1}$ Ihejirika, Peters O. ${ }^{2}$ Chinweze Reginald M. ${ }^{3}$ \\ Department of Banking and Finance, Faculty of Business Administration, Imo State University, Owerri.
}

\begin{abstract}
This study examined the causal relationship between financial deepening and unemployment in Nigeria from 1981 to 2015. Using secondary data obtained from the Central Bank of Nigeria (CBN) 2015 and from the World Development Indicators published by the World Bank, the study specifically examined the effect of financial deepening variables (ratio of credit to private sector to GDP, ratio of broad money to GDP and ratio of market capitalization to GDP) on Unemployment. The Error Correction Model (ECM) and Granger Causality Test were employed in the analysis and it was found that Credit to Private Sector and Broad money supply reduced unemployment implying that as more people gain access to finance, more job creating investments will be established to employ more people thereby reducing unemployment while Market Capitalization was not significant to influence Unemployment. In the long run all the variables were jointly found to influence unemployment and causality was found to be unidirectional flowing from financial deepening to unemployment. Among other recommendations, this study recommended that the Monetary Authority and the Government should make credit available to the citizenry especially the poor and the vulnerable.
\end{abstract}

Keywords: Financial deepening, Unemployment, Credit to Private Sector, Market Capitalization, Broad Money Supply.

DOI: $10.7176 / \mathrm{JRDM} / 58-07$

Publication date: August $31^{\text {st }} 2019$

\section{Introduction}

One of the objectives of the monetary policy of any Country is the attainment of high rate of employment and Nigeria is no exception. Yet many countries both in the developed and the developing experience unemployment which occurs when a person who is fit and is actively searching for employment is unable to find a job. According to Okereke, Sanni, Anyanwu \& Ogunbiyi (2009), there are two main reasons for worrying about unemployment first it results to economic wastes and second, it causes human suffering (poverty) with its attendant socioeconomic problems. Kyei \& Gyeke (2011) argued that "unemployment is a real matter of concern as it can yield devastating effect on economic welfare, crime, the erosion of human capital, misery and social instability."

Evidence from the literature suggest that Financial Deepening (the increased provision of financial services in an economy tailored to all levels of the society) has the capacity of reducing unemployment in two different ways through the indirect channel of economic growth and through the direct channel of access to finance by the poor and the vulnerable in the society (Claessens \& Feijen, 2006 cited in ADB, 2009). This implies that Financial Deepening will translate into unemployment reduction through some transmission mechanisms such as extending Credit to the Private Sector (CPS) measured by Credit to the Private Sector to Gross Domestic Product (CPS/GDP), increasing Broad Money Supply (M2) measured by Broad Money Supply to Gross Domestic Product (M2/GDP) and developing the Capital Market measured by Market Capitalization to Gross Domestic Product (MC/GDP). Akinlo (2014) argued that "an efficient financial sector will assist in channeling funds to the most lucrative or productive sectors as well as respond to the needs of the private sector by increasing investment, enhancing economic growth, creating job opportunities and improving income distribution." The implication is that as the financial sector grows in dept, by providing accessible financial services to all strata of the Society it will help people to establish Micro, Small and Medium Enterprises which will translate into unemployment reduction. Overwhelming evidence in the literature show that through credit to the private sector, establishment of SMEs and Micro businesses and the provision of access to finance to the rural dwellers especially for agriculture and agro allied activities such as farming, fishing etc. will reduce unemployment.

But Economists in their opinion are divided as to the influence of finance on unemployment as a component of economic development on the basis of four hypotheses (supply-Leading, Demand-following, Feedback and Neutrality hypotheses). Some economists in the like of Schumpeter (1911), Shaw (1973) etc. believe that financial deepening has a positive influence on unemployment implying that when there are more financial services such as savings mobilization, providing credit to the private sector, increase in money supply and intermediation, it will lead to capital accumulation and economic growth.

But Economists such as Robinson (1952), Friedman \& Schwartz (1963) argue that it is the development of the real 
sector that influences financial deepening while economists like Lucas (1988) argued that "the role of finance in economic development has been significantly overrated."

In Nigeria, there has been a significant growth in the financial sector over the years leading to an appreciable financial dept. For example, Credit to the Private Sector rose from 8.57 billion Naira in 1981 to 18,674 billion naira in 2015 and Broad Money Supply rose from 14.47 billion Naira in 1981 to 18,901.30 billion Naira in 2015 while Market Capitalization increased from five billion Naira in 1981 to 17,003.4 billion Naira in 2015 (CBN Statistical Bulletin, 2015). This growth scenario was graphically presented by Akinlo (2014) as resulting from Nigeria's "vast network of financial institutions, including rural finance." He argued that "for years, Government and the Central bank of Nigeria had to intervene especially with respect to stipulation of credit guidelines in favour of agriculture and agro allied activities which constitute 70 per cent of activities in the rural areas. Moreover, several programmes and schemes were implemented to enhance increased credit to the rural areas. Some of these policies include sectoral allocation of credit and concessionary interest to rural and micro entrepreneurs; the CBN introduction of the rural banking policy in 1977 that required commercial banks not only to open stipulated numbers of rural branches but also to advance not less than 50 per cent of the total deposit mobilized in the rural areas to rural borrowers". All these policies and other programmes such as the "Agricultural Development Programme (ADP), National Directorate of Employment (NDE), the Directorate of Food, Road and Rural Infrastructure (DFFRI), Better Life for Rural Women, and National Microfinance Policy and Regulatory Framework (NMPRF)." in one way or the other provided finance to the poor or the under privileged with the intention of providing employment for the citizenry and thereby reducing poverty. But unemployment has been fluctuating rising from 4.1 percent in 1981 to 10.4 percent in 2015 (World Development Indicators, published by the World Bank)

Evidence from the literature suggests that unemployment rate gauges the health of an economy and gives insight to the level of poverty existing in that country. Therefore with the evidence from the literature can one say that there is a positive significant improvement in the unemployment position in the country? Or will it be adjudged that the achieved financial dept is commensurate with the present level of unemployment in the country?

Besides, the divergent views of Economists on the finance-unemployment as a component of Economic Development have led to four hypotheses namely Supply-Leading, Demand-Following, Feedback and Neutral hypotheses. And the question is which one of these is empirically supported in Nigeria?

Therefore the objective of this study is to examine the causal relationship between financial deepening and unemployment in Nigeria from 1981 to 2015 and to proffer solutions to the following questions.

To what extent does Credit to the Private Sector to Gross Domestic Product (CPS/GDP) impact on Unemployment? What is the relationship between Broad Money Supply to Gross Domestic Product (M2/GDP) and Unemployment? And what is the effect of Market Capitalization to Gross Domestic Product (MC/GDP) on Unemployment in Nigeria?

\section{Literature Review}

The World Bank (1932), as cited in Nzotta \& Okereke (2009)" further contends that financial deepening encompasses the increase in the stock of financial assets and rom this perspective, financial deepening implies the ability of financial institutions in general, to effectively mobilize financial resources for development. This view accepts the fact that a financial system's contribution to the economy depends on the quality and quantity of its services and the efficiency with which it performs them." Obonyo (2014) argued that it refers to liquid money maintaining that the more liquid money is available in an economy, the more opportunities exist for continued and sustainable growth. It is the accumulation of financial assets at a faster pace than the accumulation of non-financial wealth and total output."

There are many different ways in which the financial sector can be said to 'develop or deepen'. For example:

- $\quad$ the efficiency and competitiveness of the sector may improve;

- $\quad$ the range of financial services that are available may increase;

- $\quad$ the diversity of institutions which operate in the financial sector may increase;

- $\quad$ the amount of money that is intermediated through the financial sector may increase;

- the extent to which capital is allocated by private sector financial institutions, to private sector enterprises, responding to market signals (rather than government directed lending by state owned banks), may increase;

- $\quad$ the regulation and stability of the financial sector may improve;

- Particularly important from a poverty reduction perspective, more of the population may gain access to 
financial services. (World Bank Report, 2004)

The theoretical link between financial deepening and unemployment as a component of economic development in the literature can be divided into four hypotheses: the Supply leading hypothesis, the Demand following hypotheses, the feedback hypothesis and the neutral hypothesis.

Dushimumukiza (2010), argues that the 'supply-leading' hypothesis posits a unidirectional causation that runs from financial deepening (financial sector development) to economic development implying that new functional financial markets and institutions will increase the supply of financial services. This will definitely lead to high but sustainable real economic growth. This hypothesis performs two roles namely to transfer resources from low growth sectors to high growth sectors and to promote entrepreneurial response in the later sector.

Earlier scholars such as Schumpeter (1912), Goldsmith (1969), Shaw (1973) and McKinnon (1973), emphasized the importance of the financial system in economic growth. Hicks (1969) argued that the industrialization process in England was promoted by the development of the financial sector which increased the access of the government and people to funds that were used to finance capital projects which led to the development of the economy. This view was also supported by King and Levine (1993).

On the other hand, the 'demand-following' hypothesis posits a unidirectional causation from economic development to financial development. This implies that it is the increasing demand for financial services by the real sector that leads to the aggressive expansion of the financial system as a result of the growth in the real sector of the economy. Robinson (1952) declares that "where enterprise leads finance follows." According to this view, economic development creates demands for particular types of financial arrangements and the financial system responds automatically to these demands. Previous studies that support this hypothesis include Gurley and Shaw (1955, 1967), Goldsmith (1969) and Jung (1986).

The feedback hypothesis presupposes that there is a bi-directional causality between financial deepening and economic development. This is empirically supported by the research studies of Levine (1997), Luintel \& Khan (1999), Demetriades \& Andrianova (2003), Odeniran \& Udeaja (2010) and Osuji \& Chigbu (2012).While the Neutral hypothesis holds that there is no causality running from either side.

A deep and mature financial system will lead to greater availability of financial services to all levels of society, lead to the increase in money being intermediated (the ratio of money supply to GDP) and increased access to finance. By mobilizing savings, facilitating payments and trade of goods and services, and promoting efficient allocation of resources, the financial sector is seen as playing a critical role in facilitating economic growth which in turn will generate employment opportunities (ADB, 2009).

More so, as the financial system performs its function of intermediation, businesses are able to access finance including the SMEs and the Micro businesses especially in the rural areas. For example, in the present economic situation of Nigeria, many people have gone into agro allied businesses such as fishing etc. thereby providing employment for them. And the SMEs are known to be labour intensive units employing more people than the bigger factories. It therefore implies that as more businesses access finance, there is room for growth and for more people to be employed thereby reducing unemployment.

Economic literature abound that provides solutions for the reduction of unemployment in economies ranging from the Classical Economic theory to the theory of Innovation, the theory of Effective Demand, the theory of the Real Business Cycle, the theory of Productivity etc. But this study will be relying on the following two theories; the Classical Economic theory and the theory of Innovation.

According to Mouhammed (2011), the classical theory, as analyzed by Pigou (1933) and Solow (1981), argues that the labour market consists of demand and supply of labour. Demand for labor is a derived demand, obtained from the declining portion of the marginal product of labour. The demand curve is a negative function of real wage in that if wages increase, the quantity demand for labour will decline and the opposite is correct. The supply of labour is derived from worker's choice whether to spend part of time working or not working (leisure). Supply of hours worked is a positive function of the real wage, because if the real wage rises, workers supply more hours of work. In equilibrium, demand and supply of labor are intersected at a clearing point that determines the equilibrium real wage rate and full employment. The argument of the classical theory implies that full employment is achieved at the point of equilibrium where supply and demand for labour meet and any deviations will result to disequilibrium which may lead to unemployment. 
Innovation Theory involves introducing something new and this theory is originally believed to have originated from the German economist Von Mangoldt (1855) who linked profit to risk. In his work, he provided several innovative ways by which the entrepreneur can make profits. These ways are (1) finding particular markets, (2) acquisition of productive agents, (3) skillful combination of factors of production, (4) successful sales policy, and (5) innovations. And Mouhammed (2010) agreed that it is a well understood proposition that entrepreneurial profits will increase employment through business growth. This proposition was supported by Schumpeter (1934) in his theory of Business Cycle as cited in Mouhammed (2011) which clearly demonstrated that innovations in the following five areas of development: "(1) the introduction of new good or of a new quality of a good. (2) The introduction of a new method of production (3) The opening of a new market (4) The conquest of a new source of supply of raw materials, or manufactured goods (5) The carrying out of the new organization of any industry, like the creation of a monopoly position or the breaking up of a monopoly position" will create jobs for the unemployed. $\mathrm{He}$ also maintained that for the continuation of the process of economic development and innovations credit and finance are important requirements: "in carrying out new combinations, financing is fundamentally necessary." He insists that Credit is a very important function in economic development because it provides funds for the entrepreneurs to materialize innovations, or to carry out the new combination. Consequently, Schumpeter (1934) argues, that the banker who has savings and creates the money (or the purchasing power) for the entrepreneur is "a phenomenon of development."

The reliance on these two theories; the Classical Economic theory and the theory of Innovation is informed by the argument of Mouhammed (2011) that even the standard microeconomic theory produces similar result with different terminology. He argued that "in this theory the marginal revenue product is MRP which is the multiplication of marginal revenue (MR) by the marginal product of labour (MPL), or productivity. Mathematically, it is MRPL $=(\mathrm{MR})(\mathrm{MPL})$. And the profit-maximizing firm will hire workers until MRPL $=\mathrm{W}$, where $\mathrm{W}$ is the given wage rate. It is assumed that the production function is of the form where output (Q) depends on two resources Labour (L) and all other resources combined as $\mathrm{O}$, and is subject to a constant return to scale, where the sum of the exponents of $\mathrm{L}$ and $\mathrm{O}$ is equal to one".

Empirical literature on the relationship between financial deepening and unemployment are few but many researchers have considered this relationship under financial deepening and poverty or economic growth nexus. The implication of this is that unemployment rate is an indication of the level of poverty that exists in an economy and an improvement in the economic growth is likely to create jobs.

Aliero et al (2013) investigated the impact of financial sector development on the level of unemployment in Nigeria using time series data generated from 1980 to 2011 period. Credit to the Private Sector (CPC), broad money supply, M2/GDP, the ratio of money supply to GDP and two other proxies of financial development indicators which they considered superior to other proxies especially to countries in early developmental stage were used. These new proxies consist of rural bank branch deposit which is denoted by rudepo and formal loan allocated to the rural dwellers by the rural bank branches which is denoted by ruloan. Bound test approach was applied and it showed that financial sector development has a long run relation with the unemployment level in Nigeria. The study found that there is persistence of unemployment in Nigeria, while credit allocation in rural areas has both short run and long run effect of reducing unemployment.

Obonyo (2014) studied financial deepening, Savings Mobilization and Poverty reduction in Kenya. Using M2/GDP as financial deepening indicator and the Johansen Cointegration model and Granger Causality Test, he found that first, financial deepening granger causes both savings and poverty reduction in Kenya. Second, the effect of financial deepening on poverty reduction in Kenya was positive, though not significant, and that there was a long run relationship between financial deepening, savings mobilization and poverty reduction and by implication to unemployment reduction.

Odhiambo (2010a) focused on the Kenyan economy to analyze the relationship between financial deepening, savings and poverty reduction. He used time series data between 1968 and 2006 and the dynamic trivariate granger causality model based on error correction mechanism. His main findings were that there is a distinct causal flow from financial deepening to both poverty reduction and savings, and that there is bi-directional causality between savings and poverty reduction implying unemployment reduction as well.

Odhiambo (2010b) investigated financial deepening and poverty reduction in Zambia. He used the Autoregressive Distributed Lag Bounds Testing procedure on three proxies of financial development, Broad Money Supply ratio to GDP (M2/GDP), Domestic Credit to Private Sector to GDP (DCP/GDP) and Deposit Money Bank Assets and found out that when Broad Money Supply ratio (M2/GDP) is used as a proxy for financial Sector development, 
poverty reduction seem to cause development of the financial sector. But when Direct Credit to the Private Sector and Deposit Money Bank Assets (DMBA) are used financial development seems to cause poverty reduction and by extension unemployment reduction.

\section{METHODOLOGY}

The research design adopted for this study is the quasi experimental design and the data used are obtained from the Central Bank of Nigeria Statistical Bulletin 2015 and from the International Labour Organization (ILOSTAT Data Base).

\section{Model Specification}

This study adopted the multi-linear econometric model of Odhiambo (2010b) with modification to analyze the effect of financial deepening on unemployment in Nigeria. Instead of the Deposit Money Bank Assets he used, this study employed Market Capitalization to GDP ratio (MCGDP) with two other variables Credit to Private Sector to GDP (CPSGDP) and Broad Money Supply to GDP based on the Ordinary Least Square (OLS) method due to its Best Linear Estimator (BLUE) possession.

This is expressed in its functional form as follows:

$\mathrm{UNEMP}=\mathrm{f}(\mathrm{CPSGDP}, \mathrm{M} 2 \mathrm{GDP}, \mathrm{MCGDP})$

Where;

UNEMP $=$ Unemployment rate

CPSGDP $=$ Credit to Private Sector to GDP ratio

$\mathrm{M} 2 \mathrm{GDP}=$ Broad Money Supply to GDP ratio

MCGDP $=$ Market Capitalization to GDP ratio

The above functional equation is further stated in econometric form as presented below:

$\mathrm{UNEMPt}=\beta 0 \mathrm{t}+\beta 1 \mathrm{CPSGDPt}+\beta 2 \mathrm{M} 2 \mathrm{GDPt}+\beta 3 \mathrm{MCGDPt}+\mathrm{Ui}$-------- (2)

Where:

$\mathrm{Ui}=$ Error Term

$\beta 0-\beta 3=$ the Parameters

A prior Expectation $=\beta 1, \beta 2, \beta 3<0$

(implying that $\beta 1, \beta 2, \beta 3$, will reduce unemployment)

\section{Analytical Procedure}

The focus of this study is to establish the relationship between financial deepening and Unemployment in Nigeria, 1981 - 2015 and to determine the direction of causality based on the above discussed theoretical postulates. To achieve this, this study adopted the Cointegration and Vector Error Correction Model (VECM) with the following procedure:

Unit Root Test

Optimal Lag Length Selection

Cointegration Test

Vector Error Correction Model (VECM)

Granger Causality Test

Operational Measures of Variables

Unemployment (UNEMP) - is the dependent variable to measure the level of unemployment in the country. It also indirectly $\mathrm{x}$-rays the extent of poverty in the nation because where unemployment is high it implies that there is poverty as many people are not earning any income and vise versa.

Ratio of Credit to Private Sector to GDP (CPS/GDP) - This is a measure of financial depth but captures the allocation of credit to the private enterprises. In other words, it measures the role of financial intermediaries in channeling funds to productive agents and possibly to the poor. The logic here is that the financial system that allocate more credit to the private firms are more into the intermediation function of mobilizing savings, providing risk management etc, that will lead to growth and create jobs.

Ratio of Broad Money Supply to GDP (M2/GDP) - This explanatory variable measures the ratio of money supply in the financial system and gives us information as per the level of intermediation in the economy and the depth of the financial system. In other words, it shows the ability of the financial systems to provide financial transactions services and saving opportunities. 
Market Capitalization to GDP $(M C A P / G D P)$ - This captures the rate of financial intermediation that takes place in the capital market of the financial system. The essence of the market capitalization ratio is that the size of the market should be positively correlated with the ability to mobilize capital and diversify risk in an economy (Demirguc-Kunt \& Levine, 1995). It shows the rate of savings that is channeled into investment.

\section{Data Analysis and Discussions}

Unit Root Test: Prior to cointegration and any other econometric analysis, it is important to establish the stationarity of the data to be used. The Test (Table 4.3) revealed that all the variables became stationary at first differencing, that is Order I(1), to meet the precondition of co-integrating model as presented below:

Johansson Co-integration Test: It is important to determine the optimum lag length due to the multivariate nature of our model which is sensitive to lag selection. The Johansson Co-integration Test conducted (Table 4.5) revealed 1 cointegrating equation at 0.05 levels both in Trace test and Max-eigen value test implying that all the variables in the model are in a long-run equilibrium relationship or association. In other words, they all move together in the long run. This long run relationship allowed the running of the Vector Error Correction Model.

Vector Error Correction Model (VECM): The VECM is a causality model and the result presents both the short run and the long run dynamics. It has the advantage of combining both the short run coefficient and the long run coefficient without losing long run equilibrium. The result of the Error Correction Term (ECT) as revealed in table 4.6 is negative (-0.525399) and significant (0.0010) validating the long run relationship. The speed of adjustment back to long-run equilibrium relationship is $52.53 \%$ meaning that in the event of any disequilibrium in the system, the variables will quickly converge back to the long-run equilibrium at the speed of $52.53 \%$. This also suggests that there is a unidirectional causality running from financial deepening to unemployment implying that the financial deepening variables jointly reduce unemployment.

Granger Causality Test: The Significance of the error correction term (ECT) in the model confirmed that all the variables are in long-run equilibrium relationship and granger cause one another. But since the regression result did not indicate which of the variables that specifically impacted on unemployment in the long-run, the Pairwise Granger Causality Test was conducted to deduce this information as an answer to the questions posed in this study. The result showed that CPSGDP with P-value 0.0006 granger caused Unemployment implying a unidirectional causality from CPS to UNEMP. M2GDP ( $p$-value 0.0001) also granger caused Unemployment implying a unidirectional causality from M2GDP to UNEMP. Market Capitalization, MCGDP (p-value 0.0873) did not granger cause Unemployment at 5\% but is significant at 10\%. This revealed that it is Credit to Private Sector and Broad Money Supply that reduced unemployment in Nigeria. Market Capitalization in Nigeria despite its acknowledged improvement did not impact on unemployment but will require reformation because of its potentials to grow.

\section{Conclusion and Recommendations}

First, Credit to Private Sector was found to reduce unemployment implying that as more people gain access to finance, more job creating investments will be established to employ more people and reduce unemployment. Second, Broad money supply was also found to reduce unemployment. The implication of this is that as more money is supplied into the system, there will be room for increased intermediation thereby leading to more people accessing finance. This will lead to Capital formation and employment which in turn will reduce unemployment. Third, despite the improvement in Capital Market development in Nigeria, it was found not to significantly impact on unemployment. This suggests that Nigeria's capital market is still shallow. This may not be unconnected with the 2007-2009 global financial crisis which badly affected the capital market. In all, this study supports the supplyleading hypothesis implying that financial deepening in any economy will lead to job creation and a reduction in unemployment through access to finance.

From the above conclusion this study recommends that Policy Makers (the Government and the Central Bank of Nigeria) should pursue the following:

Provide ways of making credit available to the citizenry. They should pursue a policy of financial inclusion to accommodate the poor and the vulnerable either through the Deposit Money Banks or Special Development Banks. This will lead to the establishment of enterprises that will generate jobs in the economy and reduce unemployment. In the case of Broad money supply, they should increase supply with a close watch at inflation. The Bail-out fund routed through the banks in 1999 and in 2011 is supported by this study.

The Nigerian Capital Market requires reformation to avoid the sharp practices of prize manipulation in the past and improve the confidence of the public. 


\section{References}

Asian Development Bank (2009). Financial Sector Development, Economic Growth and Poverty Reduction: A Literature Review, ADB Economic Working Paper Series, No.173.

Akinlo, A. E. (2014). Policy choices and challenges in expanding access to finance for growth in rural Nigeria, European Journal of Sustainable Development, 3 (1),135-144.

Aliero H.M, Ibrahim S.S., \& Shuaibu M. (2013). An empirical investigation into the relationship between financial sector development and unemployment in Nigeria, Asian Economic \& Financial Review, 3(10), 1361-1370.

Claessens, S., \& Feijen, E. (2006). Financial Sector Development and the Millennium Development Goals. World Bank Working Paper No. 89, World Bank, Washington, DC.

Demetriades, P., \& Andrianova, S. (2004). Finance and Growth: What We Know and What We Need to Know. In Goodhart C. (ed) Financial Development and Economic Growth: Explaining the Links. Basingstoke: Palgrave Macmillan, 38

Demirgue Kunt, A., \& Levine, R. (1996). "Stock market, corporate finance and economic growth: An overview" The World Bank Review, 10(2), 223-239.

Dushimumukiza, D. (2010). Financial Development and Economic Growth: The case of Rwanda, A Master of Arts in Economics dissertation to University of Mauritius.

Fitzgerald, V. (2008). Financial Development and Economic Growth; A Critical View: World Economic and Social Survey, in ADB (2004)

Friedman M. and Schwartz A.J. (1963). A Monetary History Of the United States, 1867-1960, Princeton University Press, USA, Dewey Decimal 332.4973.

Goldsmith, R. (1969). Financial structure and Development, New Haven, Yale University Press, in DFID, (2004), in ADB (2004).

Greenwood \& Jovanovic (1990). Financial Development, Growth and the Distribution of Income, Journal of Political Economy, 98 (5,1),1076-1107, in Nzotta and Okereke, (2009).

Gribbons, B., \& Herman, J. (1997) "True and quasi-experimental designs". Practical Assessment, Research \& Evaluation. 5 (14) in Wikipedia (2016) https://en.wikipedia. org/wiki/ Quasi-experiment

Gujarati, D.N. (1978). Base Econometrics. MC Grae-Hill, New York.

Gurley, J.G., \& Shaw, E.S. (1955). Financial Aspects of Economic Development, American Economic Review, 45(4), 515-38.

Hicks, John (1969). A Theory of Economic History. Oxford; Clarendon Press.

Jalilian, H., \& Kirkpatrick, C. (2001). Financial Development and Poverty Reduction in Developing Countries\|, Working Paper No. 30, IDPM, Manchester University.

Jung, W.S. (1986). Financial Development and Economic Growth. Economic Development and Cultural Change, 34, 336-346.

King, R.G., \& Levine, R. (1993a). Finance and Growth: Schumpeter Might Be Right. Quarterly Journal of Economics, 108, 717-737.

King, R., \& Levine, R. (1993b). Finance, Entrepreneurship and Growth: Theory and Evidence. Journal of Monetary Economics, 32, 513-542.

Kyei, K. A., \& Gyekye, K. B. (2011). Determinants of Unemployment in Limpopo Province in South Africa: Exploratory Studies. Journal of Emerging Trends in Economics and Management Sciences, 2(1), 54-61.

Kuznets (1995). Economic Growth and Income Inequality. American Economic Review, 45(1), 1-28, in ADB, (2009, p. 11).

Levine, R. (2002). Bank-based or market-based financial systems: which is better? Journal of Financial International 11(4), 398-428

Levine R.(1997). Financial Development and Economic Growth: Views and Agenda. Journal of Economic Literature, 35,688-726.

Lucas, R.E. Jr., (1988). On the mechanics of economic development, Journal of Monetary Economics, 22, 3-42.

Luintel, K., \& Khan, M. (1999). A Quantitative Reassessment of the Finance-Growth Nexus: Evidence from a Multivariate VAR\|, Journal of Development Economics, 60(2), 381-405.

Lustig, N.O., Arias \& Rigolini, J. (2002). Poverty Reduction and Economic Growth: A two-Way Causality. Sustainable Development Department. Technical Papers Series. Inter-American Development Bank. Washington.

Mario, R. et al (2011). Entrepreneurship, Growth and Economic Development, Frontiers in European Entrepreneurship Research, Cheltenham, UK: Edward Elgar Publishing Ltd.

Masih, A. M. M., \& Masih, R. (1997a). A comparative analysis of the propagation of stock market fluctuations in alternative models of dynamic causal linkages, Applied Financial Economics, 7, 59-74. 
Masih, A. M. M. and Masih, R. (1997b) Dynamic linkages and the propagation mechanism driving major international stock markets, Quarterly Review of Economics and Finance, 37, 859-885.

Mckinnon, R. (1973). Money and Capital in Economic Development, Washington DC: Brooking Institute.

McKinnon (1973). Money and Capital in Economic Development. Washington DC: Brookings Institute, in ADB, (2004).

Mouhammed A. (2010). Unemployment and the Entrepreneur, International Journal of Economics and Research, $1(1), 1-14$

Mukhtar T. and Rasheed S. (2010), testing the relationship between exports and imports: evidence from Pakistan using quarterly data for the period 1972-2006. Journal of Economic Cooperation and Development, 31 (1), 41-58.

Ndebbio, J.E.U. (2004). Financial Deepening, Economic Growth and Development: Evidence from Selected SubSahara African Countries, AERC Research Papers No. 142 African Economic Research Consortium.

Nzotta, S.M., \& Okereke, E.J. (2009). Financial deepening and economic development in Nigeria. African Journal of Accounting, Economics, Finance and Banking Research. 5(5), 52-66.

Appendix

Table 4.1: Unemployment Rate (UNEMP), Broad Money Supply to Gross Domestic Product Ratio (M2GDP), Credit to Private Sector Gross Domestic Product Ratio (CPSGDP) and Market Capitalization to Gross Domestic Product Ratio (MCGDP)

\begin{tabular}{|c|c|c|c|c|}
\hline YEAR & UNEMP & M2GDP & CPSGDP & MCGDP \\
\hline 1981 & 4.1 & 15.3 & 9.1 & 5.3 \\
\hline 1982 & 4.2 & 15.6 & 10.6 & 4.95 \\
\hline 1983 & 5.3 & 16.1 & 10.6 & 5.17 \\
\hline 1984 & 7.9 & 17.3 & 10.7 & 4.73 \\
\hline 1985 & 6.1 & 16.6 & 9.7 & 4.9 \\
\hline 1986 & 3.9 & 17.7 & 11.3 & 5.05 \\
\hline 1987 & 7 & 14.3 & 10.9 & 4.25 \\
\hline 1988 & 5.1 & 14.6 & 10.4 & 3.8 \\
\hline 1989 & 4.5 & 12 & 8 & 3.35 \\
\hline 1990 & 3.5 & 11.2 & 7.1 & 3.45 \\
\hline 1991 & 5.9 & 13.8 & 7.6 & 4.23 \\
\hline 1992 & 6.2 & 12.7 & 6.6 & 3.56 \\
\hline 1993 & 6.2 & 15.2 & 11.7 & 4.36 \\
\hline 1994 & 6.2 & 16.5 & 10.2 & 4.74 \\
\hline 1995 & 6.3 & 9.9 & 6.2 & 6.2 \\
\hline 1996 & 6.9 & 8.6 & 5.9 & 7.09 \\
\hline 1997 & 4.6 & 9.9 & 7.5 & 6.73 \\
\hline 1998 & 5.2 & 12.2 & 8.8 & 6.58 \\
\hline 1999 & 5.9 & 13.4 & 9.2 & 6.41 \\
\hline 2000 & 13.1 & 13.1 & 7.9 & 7.04 \\
\hline 2001 & 13.6 & 18.4 & 11.1 & 9.61 \\
\hline 2002 & 12.6 & 19.3 & 11.9 & 9.81 \\
\hline 2003 & 14.8 & 19.7 & 11.1 & 13.71 \\
\hline 2004 & 13.4 & 18.7 & 12.5 & 18.51 \\
\hline 2005 & 11.9 & 18.1 & 12.6 & 19.85 \\
\hline 2006 & 12.3 & 20.5 & 12.3 & 27.58 \\
\hline 2007 & 12.7 & 24.8 & 17.8 & 6.38 \\
\hline 2008 & 14.9 & 33 & 28.6 & 3.94 \\
\hline
\end{tabular}




\begin{tabular}{|c|c|c|c|c|}
\hline 2009 & 19.7 & 38 & 36.9 & 2.84 \\
\hline 2011 & 23.9 & 19.3 & 16.9 & 1.63 \\
\hline 2012 & 10.6 & 19.4 & 20.4 & 2.06 \\
\hline 2013 & 10 & 18.9 & 19.7 & 2.38 \\
\hline 2015 & 9 & 20.1 & 19.8 & 1.81 \\
\hline
\end{tabular}

Sources: 1. Central Bank of Nigeria Statistical Bulletin 2015; 2. International Labour Organization (ILOSTAT) Database 2015

Table 4.2: DESCRIPTIVE STATISTICS

\begin{tabular}{|c|c|c|c|c|}
\hline STATISTICS & UNEMP & M2GDP & MCGDP & CPSGDP \\
\hline Mean & 9.325714 & 17.26571 & 6.449143 & 12.83714 \\
\hline Median & 7 & 16.6 & 4.9 & 10.9 \\
\hline Maximum & 23.9 & 38 & 27.58 & 36.9 \\
\hline Minimum & 3.5 & 8.6 & 1.63 & 5.9 \\
\hline Std. Dev. & 5.174163 & 5.846263 & 5.562566 & 6.546444 \\
\hline Skewness & 1.113813 & 1.658145 & 2.301662 & 1.882284 \\
\hline Kurtosis & 3.597375 & 6.876404 & 8.188285 & 6.904706 \\
\hline Observations & 35 & 35 & 35 & 35 \\
\hline
\end{tabular}


UNEMP

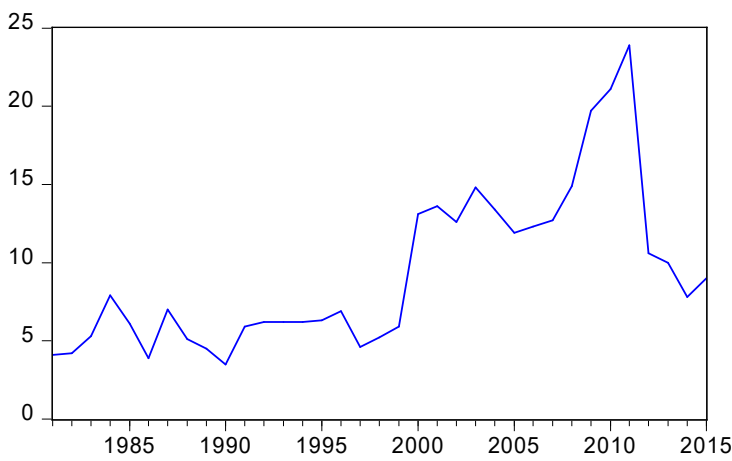

MCGDP

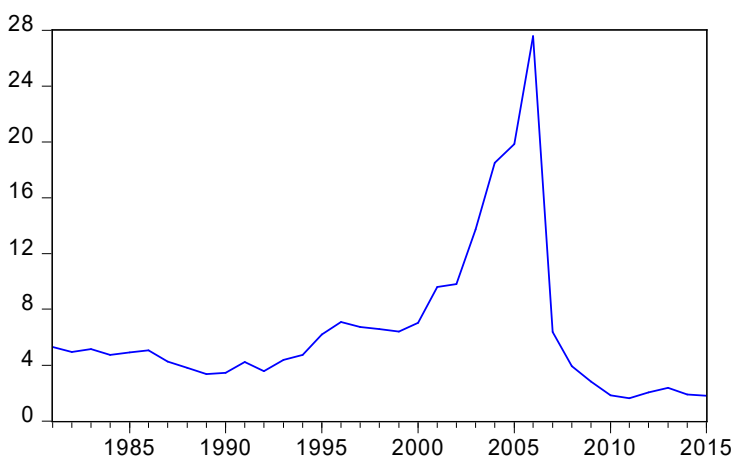

M2GDP
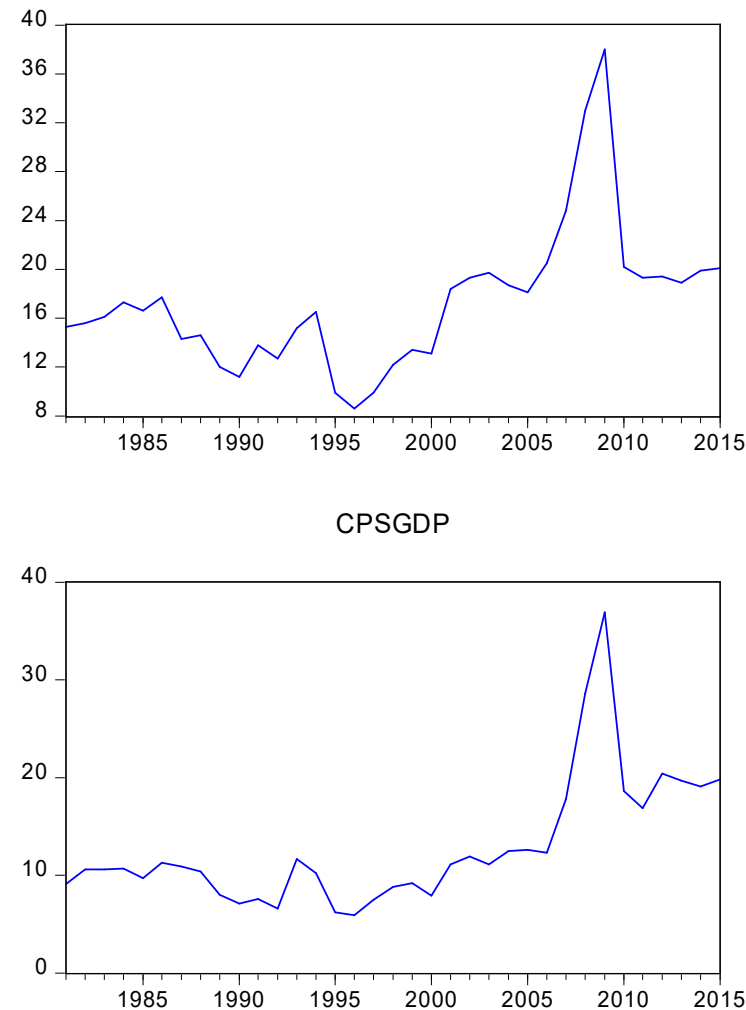

Trend analysis of UNEMP, M2GDP, MCGDP and CPSGDP 1981 - 2015

Table 4.3: Unit Root Test at Level

Group unit root test: Summary

Series: UNEMP, M2GDP, MCGDP, CPSGDP

Date: 04/28/18 Time: 08:03

Sample: 19812015

Exogenous variables: Individual effects

Automatic selection of maximum lags

Automatic lag length selection based on SIC: 0 (LEVEL)

Newey-West automatic bandwidth selection and Bartlett kernel

Balanced observations for each test

\begin{tabular}{|c|c|c|c|c|}
\hline Method & Statistic & Prob. ${ }^{* *}$ & $\begin{array}{l}\text { Cross- } \\
\text { sections }\end{array}$ & Obs \\
\hline \multicolumn{5}{|c|}{ Null: Unit root (assumes common unit root process) } \\
\hline Levin, Lin \& Chu t* & -1.71702 & 0.0430 & 4 & 136 \\
\hline \multicolumn{5}{|c|}{ Null: Unit root (assumes individual unit root process) } \\
\hline Im, Pesaran and Shin W-stat & -1.13175 & 0.1289 & 4 & 136 \\
\hline ADF - Fisher Chi-square & 10.3630 & 0.2405 & 4 & 136 \\
\hline PP - Fisher Chi-square & 10.3301 & 0.2426 & 4 & 136 \\
\hline
\end{tabular}

** Probabilities for Fisher tests are computed using an asymptotic Chi -square distribution. All other tests assume asymptotic normality. 
Table 4.4: Unit Root Test at $1^{\text {st }}$ Difference

Group unit root test: Summary

Series: UNEMP, M2GDP, MCGDP, CPSGDP

Date: 04/28/18 Time: 08:00

Sample: 19812015

Exogenous variables: Individual effects

Automatic selection of maximum lags

Automatic lag length selection based on SIC: 0 to 1 (First Difference)

Newey-West automatic bandwidth selection and Bartlett kernel

\begin{tabular}{|c|c|c|c|c|}
\hline Method & Statistic & Prob. ${ }^{* *}$ & $\begin{array}{c}\text { Cross- } \\
\text { sections }\end{array}$ & Obs \\
\hline \multicolumn{5}{|c|}{ Null: Unit root (assumes common unit root process) } \\
\hline Levin, Lin \& Chu t* & -11.3650 & 0.0000 & 4 & 131 \\
\hline \multicolumn{5}{|c|}{ Null: Unit root (assumes individual unit root process) } \\
\hline Im, Pesaran and Shin W-stat & -9.74379 & 0.0000 & 4 & 131 \\
\hline ADF - Fisher Chi-square & 84.5040 & 0.0000 & 4 & 131 \\
\hline PP - Fisher Chi-square & 104.771 & 0.0000 & 4 & 132 \\
\hline
\end{tabular}

${ }^{* *}$ Probabilities for Fisher tests are computed using an asymptotic Chi -square distribution. All other tests assume asymptotic normality.

Null: Unit root (assumes individual unit root process) : the summary result of unit root test for individual unit root process show that all the variables (UNEMP, M2GDP, MCGDP, CPSGDP) are integrated of order one i.e. I(1)

Table 4.5: Johansson Cointegration Results (see full results in appendix 1 below) Unrestricted Cointegration Rank Test (Trace)

\begin{tabular}{ccccc}
\hline \hline $\begin{array}{c}\text { Hypothesized } \\
\text { No. of CE(s) }\end{array}$ & Eigenvalue & $\begin{array}{c}\text { Trace } \\
\text { Statistic }\end{array}$ & $\begin{array}{c}0.05 \\
\text { Critical Value }\end{array}$ & Prob. $^{* *}$ \\
\hline \hline None * & 0.580888 & 56.38955 & 47.85613 & 0.0064 \\
At most 1 & 0.380818 & 27.69220 & 29.79707 & 0.0858 \\
At most 2 & 0.225069 & 11.87346 & 15.49471 & 0.1631 \\
At most 3 & 0.099514 & 3.459071 & 3.841466 & 0.0629 \\
\hline \hline Unrestricted Cointegration Rank Test (Maximum Eigenvalue) & \\
\hline \hline Hypothesized & & Max-Eigen & 0.05 & \\
No. of CE(s) & Eigenvalue & Statistic & Critical Value & Prob. ${ }^{* *}$ \\
\hline \hline & 0.580888 & 28.69735 & 27.58434 & 0.0359 \\
At mone ${ }^{*}$ & 0.380818 & 15.81874 & 21.13162 & 0.2356 \\
At most 2 & 0.225069 & 8.414388 & 14.26460 & 0.3381 \\
At most 3 & 0.099514 & 3.459071 & 3.841466 & 0.0629 \\
\hline \hline
\end{tabular}

Trace test and Max-eigenvalue test indicates 1 cointegrating eqn(s) at the 0.05 level

* denotes rejection of the hypothesis at the 0.05 level

** MacKinnon-Haug-Michelis (1999) p-values 
Table 4. 6: Result of estimated D(UNEMP) systems equation from the VECM results showing the coefficient and significance of the error term as well as the short-term relationships between unemployment and financial deepening variables.

Dependent variable D(UNEMP) See Full Results in Appendix 4

\begin{tabular}{|l|r|r|r|r|}
\hline Variable & coefficient & \multicolumn{1}{l|}{ Std. error } & t-statistic & Prob. \\
\hline Error term(-1) & -0.525399 & 0.141887 & -3.702940 & 0.0010 \\
\hline D(UNEMP(-1)) & 0.066516 & 0.161758 & 0.411208 & 0.6842 \\
\hline D(M2GDP(-1) & 0.017129 & 0.317235 & 0.053996 & 0.9573 \\
\hline (MCGDP(-1) & -0.090831 & 0.120588 & -0.753231 & 0.4578 \\
\hline D(CPSGDP(-) & -0.294014 & 0.315515 & -0.931852 & 0.3597 \\
\hline Constant & 0.215346 & 0.487268 & 0.441945 & 0.6620 \\
\hline
\end{tabular}

\section{Appendix 1}

Date: 04/28/18 Time: 08:30

Sample (adjusted): 19832015

Included observations: 33 after adjustments

Trend assumption: Linear deterministic trend

Series: UNEMP M2GDP MCGDP CPSGDP

Lags interval (in first differences): 1 to 1

Unrestricted Cointegration Rank Test (Trace)

\begin{tabular}{|c|c|c|c|c|}
\hline $\begin{array}{l}\text { Hypothesized } \\
\text { No. of CE(s) }\end{array}$ & Eigenvalue & $\begin{array}{l}\text { Trace } \\
\text { Statistic }\end{array}$ & $\begin{array}{l}0.05 \\
\text { Critical Value }\end{array}$ & Prob. .* \\
\hline None * & 0.580888 & 56.38955 & 47.85613 & 0.0064 \\
\hline At most 1 & 0.380818 & 27.69220 & 29.79707 & 0.0858 \\
\hline At most 2 & 0.225069 & 11.87346 & 15.49471 & 0.1631 \\
\hline At most 3 & 0.099514 & 3.459071 & 3.841466 & 0.0629 \\
\hline
\end{tabular}

Trace test indicates 1 cointegrating eqn(s) at the 0.05 level

* denotes rejection of the hypothesis at the 0.05 level

${ }^{* *}$ MacKinnon-Haug-Michelis (1999) p-values

Unrestricted Cointegration Rank Test (Maximum Eigenvalue)

\begin{tabular}{ccccc}
\hline \hline $\begin{array}{c}\text { Hypothesized } \\
\text { No. of CE(s) }\end{array}$ & Eigenvalue & $\begin{array}{c}\text { Max-Eigen } \\
\text { Statistic }\end{array}$ & $\begin{array}{c}0.05 \\
\text { Critical Value }\end{array}$ & ${\text { Prob. }{ }^{* *}}^{\text {None }}$ \\
\hline \hline At most 1 & 0.580888 & 28.69735 & 27.58434 & 0.0359 \\
At most 2 & 0.380818 & 15.81874 & 21.13162 & 0.2356 \\
At most 3 & 0.225069 & 8.414388 & 14.26460 & 0.3381 \\
\hline \hline
\end{tabular}

Max-eigenvalue test indicates 1 cointegrating eqn(s) at the 0.05 level

* denotes rejection of the hypothesis at the 0.05 level

${ }^{* *}$ MacKinnon-Haug-Michelis (1999) p-values

Unrestricted Cointegrating Coefficients (normalized by $b^{\prime *} S 11^{*} b=\mathrm{I}$ ):

\begin{tabular}{cccr}
\hline \hline UNEMP & M2GDP & MCGDP & \multicolumn{1}{c}{ CPSGDP } \\
-0.293616 & 0.181266 & 0.063026 & 0.109187 \\
0.097645 & 0.489917 & -0.230334 & -0.431479 \\
0.034439 & -0.432461 & -0.017204 & 0.439974 \\
0.116605 & $3.55 \mathrm{E}-05$ & 0.109932 & 0.043884
\end{tabular}


Unrestricted Adjustment Coefficients (alpha):

\begin{tabular}{|c|c|c|c|c|}
\hline $\mathrm{D}($ UNEMP) & 1.789407 & -0.395400 & -0.655956 & -0.407968 \\
\hline $\mathrm{D}(\mathrm{M} 2 \mathrm{GDP})$ & -1.451894 & -1.455016 & -1.136414 & 0.092638 \\
\hline $\mathrm{D}(\mathrm{MCGDP})$ & -1.216458 & 1.076746 & 0.018380 & -1.022053 \\
\hline $\mathrm{D}(\mathrm{CPSGDP})$ & -1.507489 & -0.779610 & -1.425248 & 0.415652 \\
\hline \multicolumn{2}{|c|}{1 Cointegrating Equation(s): } & Log likelihood & -313.6717 & \\
\hline \multicolumn{5}{|c|}{ Normalized cointegrating coefficients (standard error in parentheses) } \\
\hline UNEMP & M2GDP & MCGDP & CPSGDP & \\
\hline 1.000000 & $\begin{array}{r}-0.617358 \\
(0.37603)\end{array}$ & $\begin{array}{r}-0.214655 \\
(0.13854)\end{array}$ & $\begin{array}{r}-0.371868 \\
(0.33741)\end{array}$ & \\
\hline \multicolumn{5}{|c|}{ Adjustment coefficients (standard error in parentheses) } \\
\hline D(UNEMP) & $\begin{array}{r}-0.525399 \\
(0.14189)\end{array}$ & & & \\
\hline $\mathrm{D}(\mathrm{M} 2 \mathrm{GDP})$ & $\begin{array}{l}0.426299 \\
(0.20299)\end{array}$ & & & \\
\hline $\mathrm{D}(\mathrm{MCGDP})$ & $\begin{array}{l}0.357172 \\
(0.21599)\end{array}$ & & & \\
\hline D(CPSGDP) & $\begin{array}{l}0.442623 \\
(0.21141)\end{array}$ & & & \\
\hline
\end{tabular}

\begin{tabular}{|c|c|c|c|}
\hline \multicolumn{2}{|c|}{2 Cointegrating Equation(s): } & Log likelihood & -305.7624 \\
\hline \multicolumn{4}{|c|}{ Normalized cointegrating coefficients (standard error in parentheses) } \\
\hline UNEMP & M2GDP & MCGDP & CPSGDP \\
\hline 1.000000 & 0.000000 & $\begin{array}{r}-0.449586 \\
(0.11387)\end{array}$ & $\begin{array}{r}-0.815271 \\
(0.09962)\end{array}$ \\
\hline 0.000000 & 1.000000 & $\begin{array}{r}-0.380542 \\
(0.09173)\end{array}$ & $\begin{array}{r}-0.718227 \\
(0.08025)\end{array}$ \\
\hline
\end{tabular}

Adjustment coefficients (standard error in parentheses)

$\begin{array}{llr}\text { D(UNEMP) } & -0.564007 & 0.130646 \\ & (0.14766) & (0.24928) \\ \text { D(M2GDP) } & 0.284225 & -0.976017 \\ & (0.19558) & (0.33019) \\ \text { D(MCGDP) } & 0.462310 & 0.307013 \\ & (0.21840) & (0.36871) \\ \text { D(CPSGDP) } & 0.366499 & -0.655202 \\ & (0.21790) & (0.36786)\end{array}$

3 Cointegrating Equation(s): $\quad$ Log likelihood $\quad-301.5552$

\begin{tabular}{cccc}
\hline \hline \multirow{2}{*}{$\begin{array}{c}\text { Normalized cointegrating coefficients } \\
\text { UNEMP }\end{array}$} & M2GDP & MCGDP & CPSGDP \\
1.000000 & 0.000000 & 0.000000 & -1.240945 \\
& & & $(0.20729)$ \\
0.000000 & 1.000000 & 0.000000 & -1.078529 \\
& & & $(0.14274)$ \\
0.000000 & 0.000000 & 1.000000 & -0.946812 \\
& & & $(0.42564)$
\end{tabular}

Adjustment coefficients (standard error in parentheses) 


\begin{tabular}{cccc}
\hline & & & \\
D(UNEMP) & -0.586598 & 0.414322 & 0.215138 \\
& $(0.14328)$ & $(0.31210)$ & $(0.11018)$ \\
D(M2GDP) & 0.245088 & -0.484562 & 0.263182 \\
& $(0.18464)$ & $(0.40218)$ & $(0.14199)$ \\
D(MCGDP) & 0.462943 & 0.299065 & -0.324996 \\
& $(0.21975)$ & $(0.47866)$ & $(0.16899)$ \\
D(CPSGDP) & 0.317414 & -0.038837 & 0.109078 \\
& $(0.20193)$ & $(0.43985)$ & $(0.15529)$ \\
\hline \hline
\end{tabular}

\section{Appendix 2}

VAR Lag Order Selection Criteria

Endogenous variables: UNEMP M2GDP MCGDP CPSGDP

Exogenous variables: $\mathrm{C}$

Date: 04/28/18 Time: 10:59

Sample: 19812015

Included observations: 33

\begin{tabular}{ccccccc}
\hline \hline Lag & LogL & LR & FPE & AIC & SC & HQ \\
\hline \hline 0 & -370.3053 & NA & 83594.96 & 22.68517 & 22.86657 & 22.74621 \\
1 & -313.4932 & $96.40849^{*}$ & $7112.481^{*}$ & $20.21171^{*}$ & $21.11868^{*}$ & $20.51688^{*}$ \\
2 & -299.8256 & 19.88009 & 8588.727 & 20.35307 & 21.98562 & 20.90237 \\
\hline \hline
\end{tabular}

* indicates lag order selected by the criterion LR: sequential modified LR test statistic (each test at 5\% level), FPE: Final prediction error, AIC: Akaike information criterion, SC: Schwarz information criterion and HQ: Hannan-Quinn information criterion

\section{Appendix 3}

Vector Error Correction Estimates

Date: 04/28/18 Time: 11:03

Sample (adjusted): 19832015

Included observations: 33 after adjustments

Standard errors in ( ) \& t-statistics in []

\begin{tabular}{cr}
\hline \hline Cointegrating Eq: & CointEq1 \\
\hline \hline UNEMP(-1) & 1.000000 \\
M2GDP(-1) & -0.617358 \\
& $(0.37603)$ \\
& {$[-1.64177]$} \\
& -0.214655 \\
MCGDP(-1) & $(0.13854)$ \\
& {$[-1.54944]$} \\
CPSGDP(-1) & -0.371868 \\
& $(0.33741)$ \\
C & $7.10211]$ \\
\hline \hline
\end{tabular}




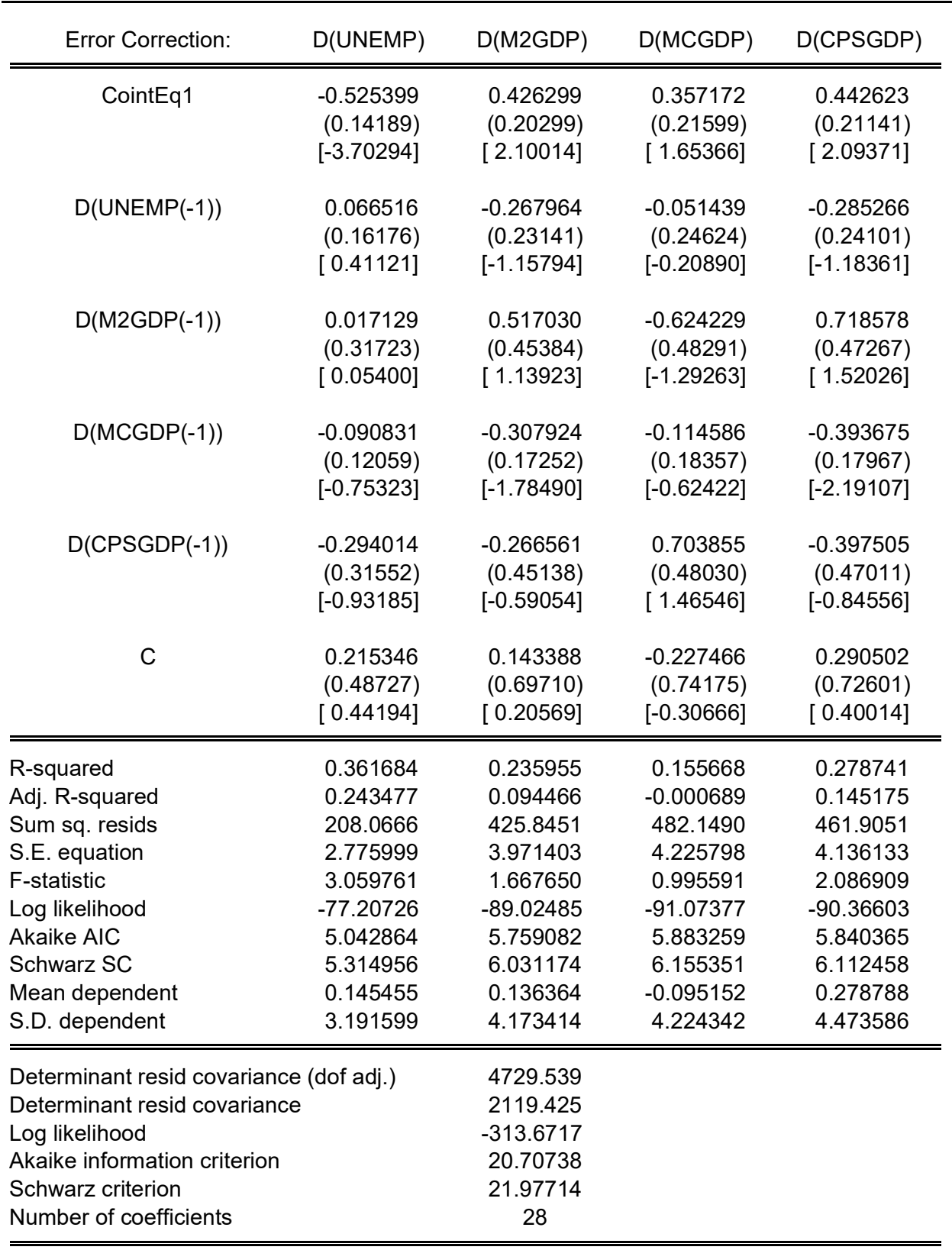




\section{Appendix 4}

Dependent Variable: D(UNEMP)

Method: Least Squares (Gauss-Newton / Marquardt steps)

Date: 04/28/18 Time: 11:05

Sample (adjusted): 19832015

Included observations: 33 after adjustments

$\mathrm{D}(\mathrm{UNEMP})=\mathrm{C}(1)^{\star}\left(\mathrm{UNEMP}(-1)-0.617358098856^{*} \mathrm{M} 2 \mathrm{GDP}(-1)-\right.$

$0.21465546531{ }^{*} \mathrm{MCGDP}(-1)-0.371868133464^{*} \mathrm{CPSGDP}(-1)+$

$7.30830960663)+\mathrm{C}(2)^{*} \mathrm{D}(\mathrm{UNEMP}(-1))+\mathrm{C}(3)^{*} \mathrm{D}(\mathrm{M} 2 \mathrm{GDP}(-1))+\mathrm{C}(4)$

${ }^{*} \mathrm{D}(\mathrm{MCGDP}(-1))+\mathrm{C}(5)^{*} \mathrm{D}(\mathrm{CPSGDP}(-1))+\mathrm{C}(6)$

\begin{tabular}{crrrr}
\hline \hline & Coefficient & Std. Error & t-Statistic & Prob. \\
\hline \hline C(1) & -0.525399 & 0.141887 & -3.702940 & 0.0010 \\
C(2) & 0.066516 & 0.161758 & 0.411208 & 0.6842 \\
C(3) & 0.017129 & 0.317235 & 0.053996 & 0.9573 \\
C(4) & -0.090831 & 0.120588 & -0.753231 & 0.4578 \\
C(5) & -0.294014 & 0.315515 & -0.931852 & 0.3597 \\
C(6) & 0.215346 & 0.487268 & 0.441945 & 0.6620 \\
\hline \hline R-squared & 0.361684 & Mean dependent var & 0.145455 \\
Adjusted R-squared & 0.243477 & S.D. dependent var & 3.191599 \\
S.E. of regression & 2.775999 & Akaike info criterion & 5.042864 \\
Sum squared resid & 208.0666 & Schwarz criterion & 5.314956 \\
Log likelihood & -77.20726 & Hannan-Quinn criter. & 5.134415 \\
F-statistic & 3.059761 & Durbin-Watson stat & 1.718545 \\
Prob(F-statistic) & 0.025782 & & \\
\hline \hline
\end{tabular}


Estimation of Vector Error Correction model (VCEM results are shown in appendix 3)

Having found that there exist a long-run relationship as indicated by the Johansson cointegration between unemployment and financial deepening variables, we estimate the error correction term (speed of adjustment) and investigate if causality can be implied through the sign of the error correction term coefficient and t-statistic probability value.

Lag specifications of (1 1) is adopted as suggested by LR: sequential modified LR test statistic (each test at $5 \%$ level), FPE: Final prediction error, AIC: Akaike information criterion, SC: Schwarz information criterion and $H Q$ : Hannan-Quinn information criterion

Table 4. 6: Result of estimated D(UNEMP) systems equation from the VECM results showing the coefficient and significance of the error term as well as the short-term relationships between unemployment and financial deepening variables. Dependent variable D(UNEMP) See Full Results in Appendix 4

\begin{tabular}{|l|r|r|r|r|}
\hline Variable & \multicolumn{1}{|l|}{ coefficient } & St. error & Prob. \\
\hline Error term(-1) & -0.525399 & 0.141887 & -3.702940 & 0.0010 \\
\hline D(UNEMP(-1)) & 0.066516 & 0.161758 & 0.411208 & 0.6842 \\
\hline D(M2GDP(-1) & 0.017129 & 0.317235 & 0.053996 & 0.9573 \\
\hline (MCGDP(-1) & -0.090831 & 0.120588 & -0.753231 & 0.4578 \\
\hline D(CPSGDP(-) & -0.294014 & 0.315515 & -0.931852 & 0.3597 \\
\hline Constant & 0.215346 & 0.487268 & 0.441945 & 0.6620 \\
\hline
\end{tabular}

\begin{tabular}{||lccc||}
\hline \hline $\begin{array}{l}\text { Painwise Granger Causality Tests } \\
\text { Date: 09/09/17 Time: } 17: 34 \\
\text { Sample: } 19812015 \\
\text { Lags: } 4\end{array}$ & & & \\
\hline \hline Null Hypothesis: & & & \\
\hline \hline CPSGDP does not Granger Cause UNEMP & 31 & 7.47884 & 0.0006 \\
UNEMP does not Granger Cause CPSGDP & & 1.03648 & 0.4108 \\
\hline \hline M2GDP does not Granger Cause UNEMP & 31 & 9.67906 & 0.0001 \\
UNEMP does not Granger Cause M2GDP & & 0.81564 & 0.5288 \\
\hline \hline MCGDP does not Granger Cause UNEMP & 31 & 2.33498 & 0.0873 \\
UNEMP does not Granger Cause MCGDP & & 0.45774 & 0.7658 \\
\hline \hline M2GDP does not Granger Cause CPSGDP & 31 & 1.19942 & 0.3390 \\
CHCOP does not Granger Cause M2GDP & & 1.23927 & 0.3233 \\
\hline \hline MCGDP does not Granger Cause CPSGDP & 31 & 29.9736 & $1 . E-08$ \\
CPSGDP does not Granger Cause MCGDP & & 0.30407 & 0.8721 \\
\hline \hline MCGDP does not Granger Cause M2GDP & 31 & 17.6649 & $1 . E-06$ \\
M2GDP does not Granger Cause MCGDP & & 0.42279 & 0.7905 \\
\hline \hline
\end{tabular}

